\title{
Occult HBV infection among Egyptian hepatocellular carcinoma patients
}

\author{
Zeinab K Hassan ${ }^{1,2}$, Mohamed M Hafez ${ }^{1,3^{*}}$, Tarek M Mansor ${ }^{1}$, Abdel Rahman N Zekri ${ }^{1}$
}

\begin{abstract}
Background: Occult HBV infection accelerates the progression of liver fibrosis, cirrhosis, and finally leading to hepatocellular carcinoma (HCC). This study analyzed the occult HBV-genotypes in HCC patients.

Methods: To achieve our objective, matched serum and tissue samples were collected from 40 HCC patients. Three sets of primers were used for the HBV-DNA detection by nested-PCR, which cover the HBV-genome; Core, Surface and $X$ genes. Genotyping system based on PCR using type-specific primers was applied on HBV-DNA positive samples.

Results: Intrahepatic occult HBV-DNA was detected in 62.5\%, whereas; Serum occult HBV-DNA were detected in only $22.5 \%$ of HCC patients. In patients' positive for both anti-HBs and anti-HBC, $10 \%$ had occult HBV in serum. In serologically negative HCV patients, 63\% had intrahepatic HBV-DNA, and 21\% had HBV-DNA in serum samples. HBV-genotype D (32\%) and B (24\%) attributed predominantly to intrahepatic HBV infections in HCC patients, whereas HBV-genotype A (4\%) and C (8\%) infections were the least observed.

Conclusion: This is the first study to show the genotypes of occult HBV infection in HCC Patients. We suggest that B or D may influence the outcome of HBV infection which may lead to the development of HCC.
\end{abstract}

\section{Introduction}

Hepatocellular carcinoma (HCC) is one of the most common malignant tumors worldwide [1] ranging between 3\% and 9\% annually [2]. In Egypt, HCC reports to account for about $4.7 \%$ of chronic liver disease patients [3]. HBV and HCV infections are strongly associated with liver cirrhosis and HCC [4]. Africa is one of the highly endemic regions of $\mathrm{HBV}$, with 5 genotypes A-E are reported as predominant genotypes in different countries $[5,6]$. HBV is a serious public health problem worldwide and major cause of chronic hepatitis, cirrhosis, and HCC $[7,8]$. The diagnosis of HBV infection is usually based on the detection of hepatitis B surface antigen (HBsAg). Occult hepatitis B is defined by the presence of HBV DNA in serum or liver in the absence of HBsAg $[9,10]$. HBV DNA can be detected in patients with chronic liver disease who are negative for HBsAg but positive for antibodies to hepatitis B core antigen (anti-HBc) [11,12]. The diagnosis depends on the

\footnotetext{
* Correspondence: mohhafez_2000@yahoo.com

'Virology and immunology Unit, Cancer Biology Department, National

Cancer Institute, Cairo University, $1^{\text {st }}$ Kasr El-Aini st, 11197 Cairo, Egypt

Full list of author information is available at the end of the article
}

sensitivity of HBV DNA assays and the prevalence of HBV infection in the population $[11,13]$.

The occult HBV infection has frequently been identified in patients with chronic HCV infection, and in such patients, this occult infection may be associated with more severe liver damage and even the development of HCC [14]. Occult HBV infection has found in individuals without HBV serological markers, past HBV infection, and with HCC patients with or without chronic hepatitis C [15]. Occult HBV infection has been associated with cryptogenic chronic hepatitis and HCC. Furthermore, some studies suggested that occult hepatitis B might affect responsiveness of chronic hepatitis $C$ to interferon therapy and disease progress [14].

There is little information of HBV genotypes and its relation to occult infection despite the importance of this infection in Egypt. Taking into consideration the impact of the fact that HBV and HCV infections are common in Egyptian HCC patients, we investigate the genotyping of occult HBV infection in Egyptian HCC patients with or without $\mathrm{HCV}$ infection.

\section{C) Biomed Central}

( 2011 Hassan et al; licensee BioMed Central Ltd. This is an Open Access article distributed under the terms of the Creative Commons Attribution License (http://creativecommons.org/licenses/by/2.0), which permits unrestricted use, distribution, and reproduction in any medium, provided the original work is properly cited. 


\section{Methods}

This study included 40 histological confirmed HCCHBsAg-negative Patients; with mean age of $55 \pm 4.9$ years, male to female ratio 4:1, who underwent surgical resection in the National Cancer Institute-Cairo University. Ten patients had HBsAg-positive samples and included as a control group, tissue and blood samples were obtained from all the patients. The study protocol was performed according to the principles of Helsinki Declaration, and informed consent was obtained from all the patients.

All serologic markers for HBV infection ( $\mathrm{HBsAg}$, anti$\mathrm{HBs}$, anti-HBc, and anti-HBs) were detected with current standard assays (Adalts, Italy) and antibodies to $\mathrm{HCV}$ with HCV EIA version 3.0 according to the manufacturer's instructions (Adalts, Italy).

\section{Detection of occult HBV DNA}

In this study, we investigated the presence of HBV DNA by nested-PCR. We use three primer sets each specific for Surface, Core, and $\mathrm{X}$ viral genomic regions, respectively, in both tumor liver tissues and sera of patients as previously described [16] (Table 1). DNA extracted from the serum by QIAGEN viral DNA extraction kit (QIAGEN) using $140 \mu \mathrm{l}$ of patient serum according to the manufacturer's procedure, and from frozen liver specimens by standard Procedures [16]. In brief, $50 \mathrm{mg}$ tissue specimens were homogenized in buffer $(150 \mathrm{mmol} / \mathrm{L} \mathrm{NaCl}, 50 \mathrm{mmol} / \mathrm{L}$ Tris- $\mathrm{HCl}$ (pH7.4), $10 \mathrm{mmol} / \mathrm{L}$ EDTA, 1\% SDS), and incubated overnight with proteinase $\mathrm{K}(800 \mu \mathrm{g} / \mathrm{mL})$ at $37^{\circ} \mathrm{C}$. After extraction with phenol/chloroform the nucleic acids were precipitated with ethanol. Nucleic acids were then resuspended and digested with pancreatic ribonuclease $(100 \mu \mathrm{g} / \mathrm{mL})$ followed by extraction with phenol/chloroform, and re-precipitation in pure cold ethanol. The DNA was resuspended in $10 \mathrm{mmol} / \mathrm{L}$ Tris- $\mathrm{HCl}(\mathrm{pH} \mathrm{7.4})$,

\begin{tabular}{|c|c|c|}
\hline \multicolumn{3}{|c|}{ Core gene } \\
\hline C1s: & 5'CTGGGAGGAGTTGGGGGA3' & 1730-1747 \\
\hline C2a: & 5'GTAGAAGAATAAAGCCC $3^{\prime}$ & $2503-2487$ \\
\hline C3s: & 5'GGTCTTTGTACTCGGAGGCTG3' & $1763-1783$ \\
\hline C4a: & 5'ATACTAACATTGACATTCCC3' & $2455-2436$ \\
\hline \multicolumn{3}{|c|}{ Surface gene } \\
\hline S-1s: & 5'AGAACATCGCATCAGGACTC3' & 159-178 \\
\hline S-2a: & 5'CATAGGTATCTTGCGAAAGC3' & $642-623$ \\
\hline S-3s: & 5'AGGACCCCTGCTCGTGTTAC3' & $181-200$ \\
\hline S-4a: & 5'AGATGATGGGATGGGAATAC3' & $619-600$ \\
\hline \multicolumn{3}{|c|}{$\bar{X}$ gene } \\
\hline X1s: & 5'CTAGCCGCTTGTTTTGCTCG3' & $1282-1301$ \\
\hline X2a: & 5'TTATGCCTACAGCCTCCTAG3' & $1666-1647$ \\
\hline X3s: & 5'GGTCTTACATAAGAGGACTC3' & 1518-1537 \\
\hline X4a: & 5'GTTCACGGTGGTCTCCAT3' & $1625-160$ \\
\hline
\end{tabular}

$1 \mathrm{mmol} / \mathrm{L}$ EDTA, and its concentration was determined by using a UV spectrophotometer (Nanodrop). Amplification of the $\beta$-actin gene was performed to test for the presence of artifacts as well as to set a baseline for tissue sample that enables the evaluation of the target genes in the HBV PCR. The amplified products were visualized on an ethidium bromide-stained $2 \%$ agarose gel.

\section{HBV-Genotype analysis}

The determination of genotypes A through $\mathrm{F}$ of hepatitis $B$ virus was done according to previous described method $[17,18]$. The sequences of PCR primers used in this study are shown in table 2 . In brief, the first and second- round PCR primers were designed on the basis of the conserved nature of nucleotide sequences in regions of the pre-S1 through $\mathrm{S}$ genes, irrespective of the six HBV genotypes [17]. P1 and S1-2 were universal outer primers. B2 was used as the inner primer with a combination called mix A for genotypes A, B, and C. The first PCR was carried out in $40 \mathrm{ul}$ of a reaction mixture containing $100 \mathrm{ng}$ of each outer primer, a $200 \mathrm{mM}$ concentration of each of the four deoxynucleotides, $2.5 \mathrm{U}$ of Taq DNA polymerase (Promega, France) $1 \times$ PCR buffer containing containing (50 $\mathrm{mM} \mathrm{KCl,} 10 \mathrm{mM}$ Tris $\mathrm{pH} 8.3$ ) and $1.5 \mathrm{mM} \mathrm{MgCl} 2$. The cycling protocol included one cycle of $5 \mathrm{~min}$ at $95^{\circ} \mathrm{C}$, followed by 40 cycles consisting of $94^{\circ} \mathrm{C}$ for $1 \mathrm{~min}, 55^{\circ} \mathrm{C}$ for $1 \mathrm{~min}$ and $72^{\circ} \mathrm{C}$ for $2 \mathrm{~min}$. Two second-round PCRs were performed for each sample, with the common universal sense primer (B2) and mix A for types A through $\mathrm{C}$ and the common universal antisense primer (B2R) and mix B for types D through F.

A $1 \mathrm{ul}$ aliquot of the first PCR product was added to two tubes containing the second sets of each of the inner primer pairs, each of the deoxynucleotides, Taq DNA polymerase, and PCR buffer, as in the first reaction. These were amplified for 40 cycles with the following parameters: preheating at $95^{\circ} \mathrm{C}$ for $5 \mathrm{~min}, 30$ cycles of amplification at $94^{\circ} \mathrm{C}$ for $1 \mathrm{~min}, 58^{\circ} \mathrm{C}$ for $1 \mathrm{~min}$, and $72^{\circ} \mathrm{C}$ for 1.30 min Genotypes of HBV for each sample were determined by identifying the genotype-specific DNA bands. The two different second-round PCR products from one sample were visualized on an ethidium bromide- stained 3\% agarose gel.

\section{Detection of HCV RNA}

Nucleic acid extraction was done by Mini-extraction kit (QIAGEN) using $140 \mu \mathrm{l}$ of patient serum according to manufacturer's procedure. RT and PCR were done as previously described [17] with primers from the most conserved 5' UTR of viral genome.

\section{Statistical analysis}

Data were analyzed by the chi-square test. A $P$ value of less than 0.05 considered statistically significant. 
Table 2 HBV genotyping primers sequence

\begin{tabular}{ll}
\hline Primer Sequence & $a$ (position, specificity, and polarity) \\
\hline First PCR & (nt 2823-2845, universal, sense) \\
P1 5'-TCA CCA TAT TCT TGG GAA CAA GA-3' & (nt 685-704, universal, antisense) \\
S1-2 5'-CGA ACC ACT GAA CAA ATG GC-3' & \\
$\begin{array}{l}\text { Second PCR } \\
\text { Mix A }\end{array}$ & (nt 67-86, types A to E specific, sense) \\
B2 5'-GGC TCM AGT TCM GGA ACA GT-3' & (nt 113-134, type A specific, antisense) \\
BA1R 5'-CTC GCG GAG ATT GAC GAG ATG T-3' & (nt 324-345, type B specific, antisense) \\
B1R 5'-CAG GTT GGT GAG TGA CTG GAG A-3' & (nt 165-186, type C specific, antisense) \\
BC1R 5'-GGT CCT AGG AAT CCT GAT GTT G-3' & \\
Mix B & (nt 2979-2996, type D specific, sense) \\
BD1 5'-GCC AAC AAG GTA GGA GCT-3' & (nt 2955-2978, type E specific, sense) \\
BE1 5'-CAC CAG AAA TCC AGA TTG GGA CCA-3' & (nt 3032-3051, type F specific, sense) \\
BF1 5'-GYT ACG GTC CAG GGT TAC CA-3' & (nt 3078-3097, types D to F specific, antisense) \\
B2R 5'-GGA GGC GGA TYT GCT GGC AA-3' &
\end{tabular}

a An " $\mathrm{M}$ " represents a nucleotide that could be either an $\mathrm{A}$ or a $\mathrm{C} ; \mathrm{a}$ " $\mathrm{Y}$ " represents a nucleotide that could be either a $\mathrm{C}$ or a T. nt: nucleotide.

\section{Results}

Characteristics of the participants were shown in table 3. Out of these forty patients, 19 had serological positive HCV infection with elevated ALT. Tissue and serum samples were considered HBV DNA reactive if at least two of the three PCR assays positive. The intrahepatic HBV genes were the Surface 18/40 (45\%), X 16/40 (40\%) and Core genes $26 / 40(65 \%)$ in the occult patients compared to $10 / 10(100 \%), 6 / 10(60 \%)$ and $6 / 10(60 \%)$ in control group respectively. There was no difference observed in prevalence of intrahepatic occult HBV infection in relation to age or sex.

In the HBsAg negative HCC patients, out of 25 intrahepatic HBV-DNA, 40\% had HCV-RNA, 72\% had liver cirrhosis. According to tumor grade 16\%, 52\% and 32\% had tumor grade I, II, and III respectively. Intrahepatic HBV DNA was detected in (25/40) 63\%, of them seven (28\%) had both X and Core genes, five (20\%) had both S and $\mathrm{X}$ genes, and $11(44 \%)$ had $\mathrm{S}$ and $\mathrm{C}$ genes. Only two cases out of $25(8 \%)$ had all genes. In the control group, HBV-DNA was detected in all liver tissues, all had $\mathrm{S}$-gene, of them six had both $\mathrm{X}$ and Core genes. Out of the twenty-five cases eleven (44\%) had both anti-HBcIgG and anti-HBs. HCV RNA was found in the serum

Table 3 The characteristics of the study subjects

\begin{tabular}{ll}
\hline Characteristics & \\
\hline No. of the participants & 40 \\
No. of the controls & 10 \\
Age-years (range)* & $55 \pm 9(25-72)$ \\
Sex Male/Female & $32 / 8$ \\
Elevated serum ALT levels with HCV Ab & $19 / 40(45 \%)$ \\
Anti-HBs & $16 / 40(40 \%)$ \\
Anti-HBC & $30 / 40(75 \%)$ \\
\hline Fin
\end{tabular}

*Expressed as mean+SD (range); ALT (normal range (0-41 IU/L). of $10 / 25$ (40\%). Nine of ten (90\%) HCV-RNA positive patients had detectable serum HBV-DNA. Seventy-two percentage of these cases $(18 / 25)$ had liver cirrhosis. HBV DNA-positive patients had significantly high tumor grade I and II compared to HBV-DNA negative patients.

In serum, HBV-DNA was detected in 20 of 40 patients (50\%), 16/40 (40\%), 13/40 (32.5\%), 4/40 (10\%) had X, S and Core gene respectively. HBV DNA were detected in only $9 / 40$ (22.5\%) of HCC patients. Among the $40 \mathrm{HCC}$ patients with different serological patterns for HBV infection, occult HBV infection was $4 / 40$ (10\%) in cases positive for both anti-HBs and anti-HBc. The overall prevalence was significantly higher for those positive for anti-HBc alone or with anti-HBs than for those negative for all markers $(\mathrm{p}=0.001)$.

This study showed, as in table 4 , that intrahepatic HBV infections are attributed predominantly to viral genotypes D and B that constituted 8/25 (32\%) and 6/25 (24\%), respectively. HBV genotypes A and C infections were the least observed and constituted $4 \%$ and $8 \%$ respectively compared $100 \%$ of HBV genotype A and D mixed infections in the control group with no other genotype observed. In addition, there was a relatively high prevalence of mixed infections of 5/25(20\%) among the studied group. One case had both genotypes A and D, 2 cases had both $B$ and $D$ and 2 cases had genotypes $\mathrm{B}$ and $\mathrm{C}$. No HBV genotype $\mathrm{E}$ or $\mathrm{F}$ was found in our study and furthermore, genotypes $\mathrm{G}$ and $\mathrm{H}$ were not determined.

In the serological HCV-related HCC, the serum occult HBV infection was $47.4 \%$ (9/19). The prevalence of occult HBV infection was higher in patients having both anti-HBs and anti-HBc 2/4 (50\%) than those having anti-HBc alone $1 / 5$ (20\%). In our previous study among 
Table 4 Correlation between clinical and virological data in the intrahepatic HBV DNA

\begin{tabular}{ll}
\hline Variables & No.(\%) \\
\hline HCV-RNA & $10 / 25(40 \%)$ \\
High AFP & $15 / 25(60 \%)$ \\
Liver cirrhosis & $18 / 25(72 \%)$ \\
Tumor Grade I & $4 / 25(16 \%)$ \\
Tumor Grade II & $13 / 25(52 \%)$ \\
Tumor Grade III & $8 / 25(32 \%)$ \\
X-gene and HBclgG +ve & $12 / 25(48 \%)$ \\
S-gene and HBclgG +ve & $16 / 25(64 \%)$ \\
C-gene and HBclgG +ve & $20 / 25(80 \%)$ \\
HBV genotype A & $1 / 25(4 \%)$ \\
HBV genotype B & $6 / 25(24 \%)$ \\
HBV genotype C & $2 / 25(8 \%)$ \\
HBV genotype D & $8 / 25(32 \%)$ \\
HBV mixed genotype & $5 / 25(20 \%)$ \\
\hline
\end{tabular}

those 25 patients with occult HBV infections, HCV genotypes 4a was the most common [19], and according to the presence or absence of occult HBV infection, there was no significant difference in the mean serum ALT level.

\section{Discussion}

Occult HBV infection is characterized by positivity for HBV DNA in HBsAg-negative patients with or without serological markers of previous HBV infection [20]. Occult HBV infection has been commonly reported among immunocompromised patients [21-23]. In Egypt, occult HBV infection is $9 / 712(1.26 \%)$ in the blood donors accepted blood donations [24]. In this study, the prevalence of the intrahepatic HBV-DNA was 63\%. Similarly, in another studies on the HCC patients, it varies from $22 \%-87 \%[12,25]$ and among general population in different countries to be ranged from $2-16 \%$ $[15,26]$. Occult HBV prevalence was significantly high among HCC, chronic hepatitis $\mathrm{C}$, or under hemodialysis $[10,27,28]$. HBV may be also reactivated in patients undergoing anti-cancer chemotherapy $[12,29]$. Occult HBV infection may occur after complete clinical recovery from acute self-limited hepatitis so; HBsAg seroclearance does not necessarily imply HBV eradication $[30,31]$. In endemic areas, the anti-HBc IgG and antiHBs as well as HBsAg were not sufficient markers to exclude HBV-DNA carriers [32].

The presence of occult HBV during chronic $\mathrm{HCV}$ infection is well described, the observed high proportion of HCV-related HCC cases show occult HBV infection, was similarly in the previous epidemiological surveys that found close relationship between the existence of $\mathrm{HCV}$ and the occurrence of HCC in HBsAg-negative HCC $[20,33,34]$. Our study showed the serum occult
HBV infection to be $47.4 \%(9 / 19)$ in HCV- HCC patients. The prevalence of occult HBV infection was particularly high among patients with HBV antibodies.

In our study, the intrahepatic HBV DNA was detected in $42.1 \%(8 / 19)$ of the HCV-Ab positive patients. Only 14.2\% (3/21) patients without HCV-Ab have HBV-DNA in the liver tissue. Similarly, its prevalence in $\mathrm{HCV}$ patients is reported to be $40-50 \%$ in liver tissue $[7,9]$. There was an elevated risk in $\mathrm{HCV}$ patients because this silent infection can affect the progression and HCC development [19].

The prevalence of occult HBV infection was higher in subjects having either anti-HBs or anti-HBc or both anti- HBs and anti-HBc. Our results revealed that in 19 patients with $\mathrm{HCV}$ infection, it was higher in patients having both anti-HBs and anti-HBc 50\% than those having anti-HBc alone 20\%. In an Egyptian chronic HCV patients study, they found that those positive for anti$\mathrm{HBc}$ had severe liver disease compared to negative ones. Serum HBV-DNA was $22.5 \%$ in anti-HBc-positive chronic HCV patients and nothing detected in antiHBc-negative chronic HCV patients [35]. Similarly, serological findings in patients with occult hepatitis $B$ and $\mathrm{HCV}$ co-infection revealed that $35 \%$ of people were HBsAb positive, $42 \%$ were anti-HBc IgG positive, and $22 \%$ were negative for both [28]. In Northern countries, no more than $5 \%$ of HBsAg-/anti-HBc+ blood donor samples contain HBV DNA [36]. In West Africa, 5\% of total HBV DNA carriers are HBsAg negative [37].

HCC patients living in endemic areas for HBV were frequently found positive for $\mathrm{HBsAg}$ and/or anti-HBc antibodies and this strong relationship was the first epidemiological evidence of HBV-related oncogenic transformation [38]. Among our $40 \mathrm{HCC}$ patients with different serological patterns for HBV infection, the prevalence of occult HBV infection was $10 \%$ in both anti-HBs and anti-HBc positive cases, and $0 \%$ in cases negative for all markers. The overall prevalence was significantly higher for those positive for anti-HBc alone or with anti-HBs than for those negative for all markers. Data presented here sowed that out of the intrahepatic HBV DNA positive cases, $56 \%$ were only anti-HBc-IgG positive, while $44 \%$ were both anti-HBc-IgG and anti$\mathrm{HBs}$ positive. A higher frequency of HBV-DNA, among anti-HBc positive patients $46 \%$ than in anti-HBc negative patients (20\%) has previously reported [39]. We suggested that while HBV is not the only factor in HCC development in Egypt, it is still one of the major risks.

Occult HBV has associated with more advanced fibrosis/cirrhosis [40]. Our study shows that $72 \%$ of the HCC patients with intrahepatic occult HBV had cirrhosis. Cirrhosis is considered as an important risk factor for the development of HCC [41-44]. In addition, occult HBV infection may favor neoplastic transformation in 
$\mathrm{HCV}$-infected patients through its contribution to cirrhosis. Many epidemiologic and molecular studies indicate that persistent HBV infection may have a critical role in the development of $\mathrm{HCC}$ in HBsAg-negative patients [45].

Using PCR primers located in several HBV genes, HBV DNA can be amplified in many tissues but not all cases [46]. In this study, intra-hepatic HBV genes were examined in the forty HCC participants in whom the Surface, $\mathrm{X}$ and Core genes were detected in $45 \%, 40 \%$, and $65 \%$, respectively. In intra-hepatic HBV DNA positive cases, $28 \%$ were positive for $\mathrm{X}$ and Core genes, $20 \%$ were positive for Surface and X genes, and $44 \%$ were positive for Surface and Core genes. Only $8 \%$ were positive for Surface, $\mathrm{X}$ and Core genes. The prevalence of occult HBV infection did not differ with age or sex. The persistent HBV infection may have a critical role in the development of $\mathrm{HCC}$ in HBsAg-negative patients. One of the markers in $\mathrm{HCC}$ cases, $\mathrm{HBsAg}(-)$, has been the presence of the HBV-X gene expression in HCC since positivity for the HBV-X protein in liver tissue in several studies reached half of the liver tissues specimens. In several reports the PCR for $S$ gene was sensitive in serum whereas the $X$ gene was sensitive in the liver [28]. The $X$ gene deregulates cell cycle control, interferes with cellular DNA repair and apoptosis, and plays an important role in interaction with p53 and Rb gene [47].

HBV genotype was a factor that influencing the frequency of occults HBV. In this study the intrahepatic HBV infections in HCC cancer patients are predominantly to viral genotypes $\mathrm{D}$ and $\mathrm{B}$ that constituted $8 / 25$ (32\%) and 6/25 (24\%), respectively. HBV genotypes A and $\mathrm{C}$ infections were the least observed and constituted $4 \%$ and $8 \%$ respectively. In addition, there was a relatively high prevalence of mixed infections of 5/25(20\%) among the studied group. One case had both genotypes A and D, 2 cases had B and D and 2 cases had genotypes B and C. Similarly, in our previous study, we found that HBV mixed genotype infections could probably be of clinical significance in HBV-induced liver diseases, in which a prevalence of mixed genotype infections in the study participants was $15.7 \%$ especially those with CAH. HBV genotype A and D mixed infections accounted for $45.5 \%$ of the total mixed infections. Occult HBV during the non-replicative phase is therefore expected to be more frequent in areas where genotypes A, D, and E are prevalent [18].

In conclusion, occult HBV infection and the HBV genotype B or D may influence the outcome of HBV infection leading to the development of hepatocellular carcinoma and may have a strong association with $\mathrm{HCV}$ in the carcinogenesis of liver. A decrease in the immune status may result in $\mathrm{HBV}$ reactivation in anti-HBs positive patients undergoing chemotherapy.

\section{Author details}

TVirology and immunology Unit, Cancer Biology Department, National Cancer Institute, Cairo University, $1^{\text {st }}$ Kasr El-Aini st, 11197 Cairo, Egypt. ${ }^{2}$ Zoology Department, Faculty of Science, King Saud University, 2457 Riyadh 11451, Saudi Arabia. ${ }^{3}$ Pharmacology Department, collage of pharmacy, King Saud University, 2457 Riyadh 11451, Saudi Arabia.

\section{Authors' contributions}

ZKH: Conceived of the study, participated in its design and coordination, sample collection and carried out the serological and molecular assays, and drafted the manuscript. MMH: participated in the study design, sample collection, carried out the molecular genotyping studies, participated in the drafted the manuscript and performed the statistical analysis and the manuscript submission. ARNZ: participated in the study design and in the editing of the manuscript. TMM: Coordinated the research effort. All authors read and approved the final manuscript.

\section{Conflicts of interests}

The authors declare that they have no competing interests.

Received: 12 December 2010 Accepted: 3 March 2011 Published: 3 March 2011

\section{References}

1. El-Serag HB: Hepatocellular carcinoma: an epidemiologic view. J Clin Gastroenterol 2002, 35(5 Suppl 2):S72-78.

2. Velazquez RF, Rodriguez M, Navascues CA, Linares A, Perez R, Sotorrios NG, Martinez I, Rodrigo L: Prospective analysis of risk factors for hepatocellular carcinoma in patients with liver cirrhosis. Hepatology 2003, 37(3):520-527.

3. Rahman El-Zayadi A, Abaza H, Shawky S, Mohamed MK, Selim OE, Badran HM: Prevalence and epidemiological features of hepatocellular carcinoma in Egypt-a single center experience. Hepatol Res 2001, 19(2):170-179.

4. Ohata K, Hamasaki K, Toriyama K, Ishikawa H, Nakao K, Eguchi K: High viral load is a risk factor for hepatocellular carcinoma in patients with chronic hepatitis B virus infection. J Gastroenterol Hepatol 2004, 19(6):670-675.

5. Borchani-Chabchoub I, Gargouri A, Mokdad-Gargouri R: Genotyping of Tunisian hepatitis $B$ virus isolates based on the sequencing of preS2 and $S$ regions. Microbes Infect 2000, 2(6):607-612.

6. Odemuyiwa SO, Mulders MN, Oyedele Ol, Ola SO, Odaibo GN, Olaleye DO, Muller CP: Phylogenetic analysis of new hepatitis B virus isolates from Nigeria supports endemicity of genotype $E$ in West Africa. J Med Virol 2001, 65(3):463-469.

7. Lok AS: Chronic hepatitis B. N Engl J Med 2002, 346(22):1682-1683.

8. Attia MA: Prevalence of hepatitis B and C in Egypt and Africa. Antivir Ther 1998, 3(Suppl 3):1-9.

9. Hou J, Wang Z, Cheng J, Lin Y, Lau GK, Sun J, Zhou F, Waters J, Karayiannis $P$, Luo K: Prevalence of naturally occurring surface gene variants of hepatitis $B$ virus in nonimmunized surface antigen-negative Chinese carriers. Hepatology 2001, 34(5):1027-1034.

10. Hu KQ: Occult hepatitis B virus infection and its clinical implications. J Viral Hepat 2002, 9(4):243-257

11. Brechot C, Degos F, Lugassy C, Thiers V, Zafrani S, Franco D, Bismuth $H$, Trepo C, Benhamou JP, Wands J, et al: Hepatitis B virus DNA in patients with chronic liver disease and negative tests for hepatitis $B$ surface antigen. N Engl J Med 1985, 312(5):270-276.

12. Paterlini P, Gerken G, Nakajima E, Terre S, D'Errico A, Grigioni W, Nalpas B, Franco D, Wands J, Kew M, et al: Polymerase chain reaction to detect hepatitis $B$ virus DNA and RNA sequences in primary liver cancers from patients negative for hepatitis B surface antigen. N Engl J Med 1990, 323(2):80-85.

13. Brechot $C$, Thiers $V$, Kremsdorf $D$, Nalpas $B$, Pol $S$, Paterlini-Brechot $P$ : Persistent hepatitis $B$ virus infection in subjects without hepatitis $B$ surface antigen: clinically significant or purely "occult"? Hepatology 2001, 34(1):194-203

14. Hou J, Liu Z, Gu F: Epidemiology and Prevention of Hepatitis B Virus Infection. Int J Med Sci 2005, 2(1):50-57.

15. Fang ZL, Zhuang H, Wang XY, Ge XM, Harrison TJ: Hepatitis B virus genotypes, phylogeny and occult infection in a region with a high incidence of hepatocellular carcinoma in China. World J Gastroenterol 2004, 10(22):3264-3268 
16. Kazemi-Shirazi L, Petermann D, Muller C: Hepatitis B virus DNA in sera and liver tissue of $\mathrm{HBsAg}$ negative patients with chronic hepatitis $\mathrm{C}$. J Hepatol 2000, 33(5):785-790.

17. Naito H, Hayashi S, Abe K: Rapid and specific genotyping system for hepatitis B virus corresponding to six major genotypes by PCR using type-specific primers. J Clin Microbiol 2001, 39(1):362-364.

18. Zekri AR, Hafez MM, Mohamed NI, Hassan ZK, El-Sayed MH, Khaled MM, Mansour T: Hepatitis B virus (HBV) genotypes in Egyptian pediatric cancer patients with acute and chronic active HBV infection. Virol J 2007, $4: 74$.

19. Zekri AR, Hafez MM, Bahnassy AA, Hassan ZK, Mansour T, Kamal MM, Khaled HM: Genetic profile of Egyptian hepatocellular-carcinoma associated with hepatitis $C$ virus Genotype 4 by $15 \mathrm{~K}$ cDNA microarray: preliminary study. BMC Res Notes 2008, 1:106.

20. Chemin I, Trepo C: Clinical impact of occult HBV infections. J Clin Virol 2005, 34(Suppl 1):S15-21.

21. Xunrong L, Yan AW, Liang R, Lau GK: Hepatitis B virus (HBV) reactivation after cytotoxic or immunosuppressive therapy-pathogenesis and management. Rev Med Virol 2001, 11(5):287-299.

22. Ishiga K, Kawatani T, Suou T, Tajima F, Omura H, Idobe $Y$, Kawasaki H: Fulminant hepatitis type B after chemotherapy in a serologically negative hepatitis $B$ virus carrier with acute myelogenous leukemia. Int J Hematol 2001, 73(1):115-118

23. Hui CK, Sun J, Au WY, Lie AK, Yueng YH, Zhang HY, Lee NP, Hou JL, Liang R, Lau GK: Occult hepatitis B virus infection in hematopoietic stem cell donors in a hepatitis B virus endemic area. J Hepatol 2005, 42(6):813-819.

24. El-Zayadi AR, Ibrahim EH, Badran HM, Saeid A, Moneib NA, Shemis MA, Abdel-Sattar RM, Ahmady AM, El-Nakeeb A: Anti-HBc screening in Egyptian blood donors reduces the risk of hepatitis $B$ virus transmission. Transfus Med 2008, 18(1):55-61.

25. Pollicino T, Squadrito G, Cerenzia G, Cacciola I, Raffa G, Craxi A, Farinati F, Missale G, Smedile A, Tiribelli C, et al: Hepatitis B virus maintains its prooncogenic properties in the case of occult HBV infection. Gastroenterology 2004, 126(1):102-110.

26. Wang JT, Wang TH, Sheu JC, Shih LN, Lin JT, Chen DS: Detection of hepatitis $B$ virus DNA by polymerase chain reaction in plasma of volunteer blood donors negative for hepatitis B surface antigen. J Infect Dis 1991, 163(2):397-399.

27. Besisik F, Karaca C, Akyuz F, Horosanli S, Onel D, Badur S, Sever MS, Danalioglu A, Demir K, Kaymakoglu S, et al: Occult HBV infection and YMDD variants in hemodialysis patients with chronic HCV infection. J Hepatol 2003, 38(4):506-510

28. Torbenson M, Kannangai R, Astemborski J, Strathdee SA, Vlahov D, Thomas DL: High prevalence of occult hepatitis B in Baltimore injection drug users. Hepatology 2004, 39(1):51-57.

29. Idilman R, Arat M, Soydan E, Toruner M, Soykan I, Akbulut H, Arslan O, Ozcan M, Turkyilmaz AR, Bozdayi M, et al: Lamivudine prophylaxis for prevention of chemotherapy-induced hepatitis $B$ virus reactivation in hepatitis B virus carriers with malignancies. J Viral Hepat 2004, 11(2):141-147

30. Blackberg J, Kidd-Ljunggren K: Occult hepatitis B virus after acute selflimited infection persisting for 30 years without sequence variation. J Hepatol 2000, 33(6):992-997.

31. Marusawa H, Uemoto S, Hijikata M, Ueda Y, Tanaka K, Shimotohno K, Chiba T: Latent hepatitis B virus infection in healthy individuals with antibodies to hepatitis B core antigen. Hepatology 2000, 31(2):488-495

32. Sardo MA, Rodino G, Brancatelli S, Pernice M, Campo S, Squadrito G Russo F, Raimondo G: Inapparent "wild-type" and "e-minus variant" HBV infection in patients with HCV-related chronic hepatitis. Liver 1994, 14(5):241-244

33. Matsuzaki Y, Chiba T, Hadama T, Asaoka H, Doy M, Shoda J, Tanaka N, Kinoshita M: HBV genome integration and genetic instability in HBsAgnegative and anti-HCV-positive hepatocellular carcinoma in Japan. Cancer Lett 1997, 119(1):53-61.

34. Kim K, Kim KH, Kim HH, Cheong J: Hepatitis B virus $\mathrm{X}$ protein induces lipogenic transcription factor SREBP1 and fatty acid synthase through the activation of nuclear receptor LXRalpha. Biochem J 2008, 416(2):219-230.

35. El-Sherif A, Abou-Shady M, Abou-Zeid H, Elwassief A, Elbahrawy A, Ueda Y, Chiba T, Hosney AM: Antibody to hepatitis B core antigen as a screening test for occult hepatitis B virus infection in Egyptian chronic hepatitis C patients. J Gastroenterol 2009, 44(4):359-364.

36. Kleinman SH, Kuhns MC, Todd DS, Glynn SA, McNamara A, DiMarco A, Busch MP: Frequency of HBV DNA detection in US blood donors testing positive for the presence of anti-HBc: implications for transfusion transmission and donor screening. Transfusion 2003, 43(6):696-704

37. Allain JP: Occult hepatitis B virus infection. Transfus Clin Biol 2004 11(1):18-25.

38. Llovet JM, Burroughs A, Bruix J: Hepatocellular carcinoma. Lancet 2003, 362(9399):1907-1917

39. Cacciola I, Pollicino T, Squadrito G, Cerenzia G, Orlando ME, Raimondo G: Occult hepatitis B virus infection in patients with chronic hepatitis $C$ liver disease. N Engl J Med 1999, 341(1):22-26.

40. Stransky J, Malina L, Cieslarova B, Stritesky J, Putova I, Horak J: Overt and hidden coinfection with hepatitis $B$ and $C$ viruses in chronic liver disease and porphyria cutanea tarda. Acta Virol 2000, 44(1):23-28.

41. Fukuda R, Ishimura N, Niigaki M, Hamamoto S, Satoh S, Tanaka S, Kushiyama Y, Uchida Y, Ihihara S, Akagi S, et al: Serologically silent hepatitis $B$ virus coinfection in patients with hepatitis $C$ virus-associated chronic liver disease: clinical and virological significance. J Med Virol 1999, 58(3):201-207.

42. Nirei K, Kaneko M, Moriyama M, Arakawa Y: The clinical features of chronic hepatitis $C$ are not affected by the coexistence of hepatitis $B$ virus DNA in patients negative for hepatitis B surface antigen. Intervirology 2000, 43(2):95-101.

43. Zhang YY, Guo LS, Li L, Zhang YD, Hao LJ, Hansson BG, Nordenfelt E: Hepatitis B virus DNA detected by PCR in sera and liver tissues of Chinese patients with chronic liver diseases. Chin Med J (Engl) 1993, 106(1):7-12.

44. Ikeda K, Saitoh S, Koida I, Arase Y, Tsubota A, Chayama K, Kumada H, Kawanishi M: A multivariate analysis of risk factors for hepatocellular carcinogenesis: a prospective observation of 795 patients with viral and alcoholic cirrhosis. Hepatology 1993, 18(1):47-53.

45. Huo TI, Wu JC, Lee PC, Chau GY, Lui WY, Tsay SH, Ting LT, Chang FY, Lee SD: Sero-clearance of hepatitis B surface antigen in chronic carriers does not necessarily imply a good prognosis. Hepatology 1998, 28(1):231-236.

46. Takeuchi M, Okamoto E, Fujimoto J: [Detection of HBV-DNA from hepatocellular carcinoma by polymerase chain reaction]. Nippon Rinsho 1995, 53 Suppl(Pt 2):718-722.

47. Ding $X$, Park YN, Taltavull TC, Thung SN, Jin X, Jin Y, Trung NS, Edamoto $Y$, Sata T, Abe K: Geographic characterization of hepatitis virus infections, genotyping of hepatitis B virus, and p53 mutation in hepatocellular carcinoma analyzed by in situ detection of viral genomes from carcinoma tissues: comparison among six different countries. Jpn J Infect Dis 2003, 56(1):12-18.

doi:10.1186/1743-422X-8-90

Cite this article as: Hassan et al:: Occult HBV infection among Egyptian hepatocellular carcinoma patients. Virology Journal 2011 8:90.

\section{Submit your next manuscript to BioMed Central and take full advantage of:}

- Convenient online submission

- Thorough peer review

- No space constraints or color figure charges

- Immediate publication on acceptance

- Inclusion in PubMed, CAS, Scopus and Google Scholar

- Research which is freely available for redistribution

Submit your manuscript at www.biomedcentral.com/submit
C Biomed Central 